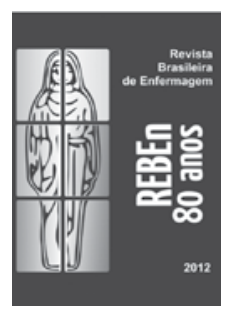

\title{
Confronting moral distress in Nursing: recognizing nurses as moral agents
}

\author{
Fazendo frente ao sofrimento moral na Enfermagem: reconhecendo as enfermeiras como agentes morais \\ Enfrentando la angustia moral en Enfermería: reconociendo las enfermeras como agentes morales
}

Franco A. Carnevale ${ }^{1}$

'McGill University, Ingram School of Nursing. Montreal Children's Hospital. Montreal, Canada.

Submissão: 08-07-2013 Aprovação: 10-07-2013

\begin{abstract}
The concept of moral distress has brought forth a substantively different way of understanding some of the difficulties confronted by nurses in their practice. This concept highlights that nurses' distress can be an indication of nurses' conscientious moral engagement with their professional practice that has confronted practices or an environment that impedes them from acting according to their own ethical standards. Moral distress can be an indicator of problems in nurses' practice environments. This concept is described and related to moral agency in nursing practice. Selected research on moral distress is reviewed, followed by a discussion of recommendations for addressing this problem.
\end{abstract}

Key words: Ethics; Moral Agency; Moral Distress; Nursing; Voice.

\section{RESUMO}

O conceito de sofrimento (ou angústia) moral trouxe à luz uma maneira substancialmente diferente de compreender algumas das dificuldades enfrentadas pelos enfermeiros em sua prática. Este conceito destaca que o sofrimento dos enfermeiros pode ser um indicador de um engajamento moral consciencioso dos enfermeiros com sua prática profissional, que têm confrontado práticas ou um ambiente que os impede de agir de acordo com seus próprios padrões éticos. Sofrimento moral pode ser um indicador de problemas nos ambientes de prática dos enfermeiros. Este conceito é descrito e relacionado a agência moral na prática da Enfermagem. É revista uma pesquisa selecionada sobre sofrimento moral, seguida de uma discussão de recomendações para enfrentar este problema.

Descritores: Ética; Agência Moral; Sofrimento Moral; Enfermagem; Voz.

\section{RESUMEN}

El concepto de angustia moral ha iluminado una forma sustancialmente diferente de entender algunas de las dificultades enfrentadas por los enfermeros en su práctica. Este concepto pone de relieve que el sufrimiento de los enfermeros puede ser una indicación de conciencia de compromiso moral con su práctica profesional, en que han enfrentado prácticas o un entorno que les impide de actuar de acuerdo con sus propias normas éticas. Angustia moral puede ser un indicador de problemas en los entornos de la práctica de los enfermeros. Este concepto es descrito y relaciona con la agencia moral en la práctica de Enfermería. Investigación seleccionada en la angustia moral es revisado, seguido de un debate sobre las recomendaciones para hacer frente a este problema.

Palabras clave: Ética; Agencia Moral; Angustia Moral; Enfermería; Voz. 


\section{ENCOUNTERS WITH MORAL DISTRESS}

The following scenarios have been adapted from my clinical practice as a nurse and clinical ethicist. Some details have been modified to protect the confidentiality of the persons involved.

\section{We don't have enough nurses!}

It is the evening shift on a very busy medical-surgical unit and two of the four nurses scheduled to work have called in sick. Only two nurses remain. Each nurse will have twice as many patients as usual. This is especially problematic because the number of nurses that work on this unit has already been reduced from five to four because of budget reductions; nurses already find it difficult to provide adequate care. The nurses reported their profound worry about their workload to their nursing supervisor but the supervisor told them that there was nothing that she could do and instructed them to do their best.

\section{He is not competent!}

A new surgeon has been hired at a small hospital. Everyone is excited because he has highly specialized training from a world-renowned university. This will improve services available to the community and elevate the reputation of the hospital. Within a few days after his arrival, the nurses in the operating room observe that the surgeon's surgical technique appears awkward; he does not seem confident. The nurses observed several 'accidents' during his operations. It is especially evident that his patients have much more bleeding than similar patients when they were operated on by the previous surgeon. Two patients died in the operating room in the first two weeks. The nurses thought that these deaths were preventable because the operations were low-risk. The nurses believed that these patients died and other patients had severe surgical complications because the surgeon was not adequately competent to perform these interventions. Two nurses reported their opinions to their supervisors and to some senior physicians in the hospital; also stating that previous and future patients should be informed about this problem. They were told that it was not within their field of expertise to assess a surgeon's competence and that they should carry on working and be quiet with their worries.

\section{Why are we doing all this?}

A patient in the intensive care unit, who was admitted with septic shock, now has multiple organ-system dysfunctions. He is requiring highly intensive resuscitative measures to sustain his life. Meanwhile, all of the staff believes that he will not survive this situation. Some of the nurses questioned a senior physician about why all of this highly invasive and costly care was being provided when there seemed to be no hope for survival. The physician replied that the medical team did not feel comfortable withdrawing life-sustaining treatment, when the patient's vital functions could still be sustained. The nurses objected, feeling that they were providing 'futile' care. They felt like they were harming the patient needlessly. Yet, they also felt that they had no choice but to comply with the medically prescribed treatments. They continued to provide the highly invasive treatments, but with great personal difficulty.

\section{Patients should not suffer in pain!}

Some of the nurses in an oncology service just returned from a conference where they learned about many innovative ways to control cancer-related pain, using both pharmacological and non-pharmacological interventions. They learned that it is possible for these patients to be comfortable and free of pain most of the time. However, when they tried to communicate what they learned to their nursing and physician colleagues, as well as their supervisors, they were told that (a) the pharmacological approaches they learned about were dangerous and could cause 'drug addiction' in patients and (b) the non-pharmacological strategies (e.g., guided imagery, relaxation) were not scientifically proven and not cost-effective for their centre. The nurses did not find these replies convincing; the conference presenters provided them with scientific evidence to demonstrate the effectiveness of these interventions. But, no one that they worked with was interested in reading this evidence. These nurses now found it very troubling to care for their patients with inadequately controlled pain.

\section{A person should die with dignity!}

One nurse had worked in palliative care for ten years, but recently transferred to an oncology unit. She has become increasingly disturbed by the fact that death is never discussed openly with patients on this unit; not even with the end-stage cases when there is no hope of cure and death is imminent. Sometimes family members are told in ambiguous terms that 'there is nothing more that we can do', but this is never discussed with the patient. Moreover, this nurse had learned in palliative care that patients with a terminal illness require: a maximization of their quality of life; vigilant management of discomforts and symptoms; optimally humanized care; open discussion of death; and treatment with respect and dignity. In this oncology unit, she is finding that the staffs are uncomfortable talking about death; patients seem to be worrying in isolation. Patients are also suffering with many discomforts, but their suffering does not seem to be treated seriously by the staff. She is very upset; feeling that many patients are dying in a deeply undignified, inhumane manner.

\section{What about what is best for the child?}

The nurses in one pediatric unit have been very proud because they have developed a strong orientation toward family centered care. They have an open policy for parents who can remain with their hospitalized child as much as they wish and parents are encouraged to actively participate in the child's care as well as treatment planning. However, from time to time, some of the nurses are stressed by situations where parents request or even demand treatments that the nurses do not think are the best option for the child. For example, parents who are Jehovah's Witnesses refuse blood products for their children even when they are urgently required to sustain the child's life. In other situations, some parents have religious views that regard life as sacred and should be preserved 
regardless of the suffering and lack of hope for a recovery for the child; e.g., children with degenerative cognitive and neuromuscular conditions whose parents demand that they be admitted to the intensive care unit for mechanical ventilation even when it is predicted that the child will never be able to breath independently. In such cases, nurses in this unit feel torn between respecting the parents' wishes and doing what the nurses themselves believe is best for the child.

\section{It's difficult to be a nursing student!}

A group of final year nursing students complained about one unit where they were required to do a clinical rotation. As final year students, they had a fairly strong foundation in the current standards in nursing practice. However, when they worked with their nursing preceptors in this unit, they were regularly confronted by practices that they had learned were unacceptable. They noted that their preceptors did not: perform vigilant physical assessments; communicate with patients respectfully; use current evidence-based standards in wound care; consistently wash their hands; among many other problems. Moreover, the students felt pressured to act in the same manner as their preceptors in order to be accepted. On occasions when students questioned current practices or tried to practice differently from their preceptors, the students felt criticised by their preceptors. The students felt they were obliged to practice badly.

\section{UNDERSTANDING MORAL DISTRESS}

I am confident that every reader has confronted situations like these and many more. In each of these situations, nurses (or nursing students) felt pressured to act in an ethically wrong manner. These situations were very distressing, yet the nurses' distress did not seem to be recognized as important.

In the past, these distresses were generally regarded as simple psychological or emotional distress - a part of the stresses of nursing. Just like the nurses in the situations described above, nurses have been told that they have a duty to follow medical and administrative directives; that it is not their place to question the authority of others. If they found their work distressing, then they have been directed to find ways to accept their work conditions, sometimes take time off from work (e.g., a 'mental health' leave for burnout), or possibly consider changing jobs.

Nurses' distress has been commonly regarded as a result of the nurses' personal weakness, which could be solved by rest, changing coping strategies, or employment relocation. The working environments and the practices in those environments were generally not questioned or considered a central part of the problem.

The concept of moral distress has brought forth a substantively different way of understanding these situations. This concept highlights that nurses' distress in situations such as these is not necessarily an indication of personal weakness. Rather, this can be an indication of nurses' conscientious moral engagement with their professional practice that has confronted practices or an environment that impedes nurses from acting according to their own ethical standards. Moral distress can be an indicator of weaknesses in the practice environment rather than nurses' weaknesses.

The American philosopher Andrew Jameton is generally credited for highlighting moral distress as a phenomenon in nursing ${ }^{(1)}$. Although this concept has been defined in somewhat varied ways over the years, moral distress generally refers to an experience when a person knows what is right to do but does not do it because of external or internal impediments to the person's actions. In nursing, this can refer to feelings such as frustration, guilt, anger, or powerlessness resulting from situations where a nurse is actually - or believes she is - constrained from acting in an ethically right manner ${ }^{(2-4)}$.

These constraints can refer to external administrative, legal, or social barriers to certain actions (e.g., unclear responsibilities for patient safety in conditions of severe understaffing; ambiguous standards regarding the withdrawal of life-sustaining treatments or the administration of high-dose opioids for pain control in terminal illness) or internal barriers (e.g., when a nurse's personal values conflict with actions required by professional standards in cases such as abortion, withdrawing enteral feedings, euthanasia, or blood refusal by Jehovah `s Witnesses) $)^{(2-4)}$.

A growing body of literature has demonstrated that moral distress is a significant concern in nursing that can lead to profoundly disturbing personal experiences; sometimes resembling what has been traditionally referred to as 'burnout'(5).

There is also an emerging belief that nurses are particularly vulnerable to experiencing moral distress because of the 'in-between moral binds' that are inherent in the profession ${ }^{(6)}$. Nurses are commonly in situations where they feel 'caught in the middle' between patients/families and physicians or patients/families and administrators, where nurses know that they have significant responsibilities toward the patients and families assigned to them, yet have very limited authority to control the conditions and standards within which they practice.

A fuller understanding of these tensions requires a recognition of the moral agency of nurses ${ }^{(2)}$.

\section{NURSES AS MORAL AGENTS}

Moral distress in nursing seems rooted in a longstanding under-recognition of the moral complexity of nursing ${ }^{(7)}$. Throughout much of its history, nursing has been regarded a profession of self-sacrifice, duty, and service; that a nurse's primary responsibility is to follow the directives of the physician.

However, in recent decades, in many regions of the world, there has been a growing recognition of the complexity of nursing practice and nurses' accountability for their practice and for ensuring that they have the required competencies for the care they provide ${ }^{(8-10)}$. Nursing codes of ethics have become commonplace ethical and legal instruments for explicitly stating nurses' obligations toward patients, their community, their nursing and inter-professional colleagues, as well as the nursing profession. Nursing practice is increasingly recognized as a moral endeavour. 
In recent years, the moral realm of nursing practice has been articulated with the concept of moral agency (for a comprehensive discussion of moral agency in nursing, see Rodney at al) $)^{(2)}$

Moral agency implies a richer conception of the moral dimension of nursing practice than has been traditionally conveyed through codes of ethics. Codes of ethics provide valuable outlines of 'deontological rules' that must be followed by a profession, but such codes describe only 'minimalist' aspects of the moral terrain of 'good nursing'. Following codes of ethics is necessary but not sufficient for defining moral agency in nursing ${ }^{(2,11-12)}$.

In philosophy, agency has been generally defined as the capacity for a person to engage in deliberate action ${ }^{(2)}$. In turn, moral agency has been commonly construed as a person's capacity to engage in deliberate actions that are morally relevant; i.e., touching on matters of right and wrong, good and bad, or just and unjust.

Traditional conceptions of moral agency have been critiqued and re-construed over the years. Salient within nursing ethics discourse have been feminist critiques of moral agency based on male-centered traditions of thought that have over-emphasized rationality, autonomy, and self-interest, disregarding the relational and contextual basis of moral agency ${ }^{(13-14)}$. Persons are not solely self-interested, nor are they fully free to independently pursue their own interests. They are relationally embedded within (a) a socio-political world that shapes available (or morally sanctioned) courses of action and (b) a network of meaningful relationships where the interests of others also matter.

This outlook is congruent with emerging conceptions of nursing ethics; nurses are moral agents within a relational socio-political meaningful world. Understanding the moral basis of nursing requires an examination of the complex 'relational socio-political meaningful' contexts within which nurses practice. Individual nurses are not free to shape the ethical standards of their profession, nor are they free to act in any manner that they individually choose. These standards and actions are always socio-politically embedded.

\section{SELECTED RESEARCH EXAMINATIONS OF MORAL DISTRESS}

Given the relatively recent development of moral distress as a concept, related research is under-developed. Important advances to date have included the validation of a measurement instrument, the Moral Distress Scale ${ }^{(15)}$, followed by a growing number of studies aiming to identify the occurrence of moral distress across nursing practice settings and across countries.

In a Brazilian investigation examining the trans-cultural validity of the Moral Distress Scale, four constructs were identified as particularly relevant for moral distress in Brazilian nursing: (a) negation of the role of the nurse as the patient's advocate; (b) lack of competency in the work team; (c) disrespect of the patient's autonomy; and (d) therapeutic obstinacy ${ }^{(16)}$. Interestingly, these four constructs are clearly apparent in the scenarios presented at the beginning of this article.

An integrative review of the international literature on moral distress in nursing, conducted in Brazil, identified the principal features of this concept $t^{(5)}$. These include personal manifestations such as emotional and physical alterations and professional manifestations such as job dissatisfaction, burnout, and abandonment of the profession. This study also reported three dimensions of coping strategies that have been identified to date: educational, communicative, and organizational.

Some research is examining moral distress through qualitative methodologies as well as inter-professional perspectives. It is increasingly recognized that moral distress can be experienced in all health care professions and that some of the causes and solutions for addressing this concern are rooted in the inter-relations between these professions. I was a co-investigator in a recent Canadian study (which also included a Brazilian-Canadian physician as a co-investigator), that examined moral distress across health care professionals working in pediatric intensive care settings ${ }^{(17)}$. A narrative inquiry methodology was used to identify the 'types of stories' that underlie the experiences of staff working with critically ill children. Five types of stories were identified: (a) stories bearing witness; (b) stories of collusion; (c) stories of resistance; (d) phantom stories; and (e) untold stories ${ }^{(17)}$.

It is very clear that moral distress requires much more research in nursing as well as other health care professions. Its diverse manifestations need to be further documented. Personal and contextual factors that precipitate or diminish moral distress as well as strategies for resolving this problem need to be better understood, using a variety of methodologies across a diversity of settings.

\section{RECOMMENDATIONS FOR ADDRESSING MORAL DISTRESS}

The scenarios presented at the beginning of this article are real and reflect many of the difficulties confronted by nurses on a daily basis. It is difficult to formulate convincing approaches for preventing or addressing moral distress, given that this concept is still quite poorly understood and strategies have been weakly evaluated to date. However, moral distress will persist within the daily realities of nurses. I therefore offer the following recommendations on the basis of the limited knowledge that is available.

One key initiative should be undertaken urgently to confront moral distress in nursing: the recognition of nurses as moral agents. The moral complexity of nursing practice has been discounted for far too long, as illustrated in the scenarios at the beginning of this article.

It is increasingly recognized that nurses should be - and have been - morally engaged in their professional practice. They are expected to ensure ethically-rich nursing care and should advocate for ongoing improvements in patient care, particularly when they identify problematic situations that may compromise the health and safety of their patients and families.

One strategy for better recognizing the moral agency of nurses is by attending to nurses 'voices. 'Voice' is a vital 
aspect of agency. Agents attempt to pursue their aims through expression - verbal and nonverbal. It is clearly evident in the scenarios at the beginning of this article that the nurses' concerns were not listened to. These nurses had insights into how the provision of care and promotion of patient safety could be improved; they attempted to express their opinions but they were discounted.

This problem can be addressed through an adaptation of the strategies identified by de Lima Dalmolin et al. ${ }^{(5)}$ : educational, communicative, and organizational. Nursing education programs (i.e., undergraduate and graduate as well as continuing education) should promote the development of nurses' capacities to (a) articulate their morally distressing concerns and (b) act to advocate for the resolution of these concerns.

The development of these capacities will require innovative teaching and learning initiatives, including strategies to promote inter-professional communication and collaboration ${ }^{(18)}$. A promising pedagogical approach to inter-professional education is advanced clinical simulation, with the use of standardized patients (frequently performed by professional actors) ${ }^{(19)}$. These types of simulations can provide challenging realistic scenarios that require participants to explore new approaches, individually and inter-professionally. Structured debriefing exercises can help further develop self-reflection and learning.

However, the responsibility for addressing morally distressing problems should not rest entirely on the shoulders of nurses. Although nurses should learn how to optimize their ability to identity and act on moral problems, their practice environments also need to develop structures and processes for preventing and resolving such problems ${ }^{(20)}$.

Clear and safe channels should be developed for nurses to voice their moral concerns as high in the organizational hierarchy as possible. In some health care organizations (e.g., hospitals), regulations require that nurses elect a nursing representative for the board of directors, to ensure that (a) nurses' concerns are attended to and (b) nursing input is sought consistently in senior administrative decisions.

Moreover, with the ongoing development of clinical ethics consultation resources in health care settings (e.g., ethics consultants, clinical ethics committees) ${ }^{(21)}$, these resources should be sensitized to nursing ethical concerns and moral distress so they can provide guidance for nurses seeking to reconcile these concerns.

Finally, professional nursing associations should consider providing advisory guidance to their members facing moral distress, as these associations will have members with advanced expertise in defining the standards for ethical nursing in various practice environments.

\section{CONCLUDING REMARK}

Some literature is highlighting that nurses can or should demonstrate moral courage in the face of ethically problematic situations; requiring nurses to confront potential personal risks, even potential injury to personal reputation or possible loss of employment ${ }^{(22-23)}$.

This is a highly controversial position as it seems to unfairly situate moral responsibility solely with nurses. Although nurses should commit to the ongoing development of their capacities for addressing moral distress, health care organizations and professional associations should also develop initiatives for preventing and resolving moral distress among nurses ${ }^{(2)}$.

These measures are urgently needed to ensure a significant reduction in the types of morally distressing problems confronted by nurses, such as those described at the beginning of this article.

\section{REFERENCES}

1. Jameton A. Nursing practice: The ethical issues. Englewood Cliffs: Prentice-Hall; 1984.

2. Rodney P, Kadyschuck S, Liaschenko J, Brown H, Musto L, Snyder N. Moral agency: Relational connections and support In: Storch JL, Rodney P, Starzomski R. Toward a moral horizon: Nursing ethics for leadership and practice. 2nd ed. Toronto: Pearson Education; 2012. p. 160-187.

3. Austin W, Kelecevic J, Goble E, Mekechuk J. An overview of moral distress and the paediatric intensive care team. Nurs Ethics 2009;16(1):57-68.

4. Carnevale FA. The birth of tragedy in pediatrics: a phronetic conception of bioethics. Nurs Ethics 2007;14(5):571-582.

5. Dalmolin GL, Lunardi VL, Barlem ELD, Silveira RS. Implications of moral distress on nurses and its similarities with burnout. Texto \& Contexto Enferm 2012;21(1):200-208.

6. Hamric AB. Reflections on being in the middle. Nurs Outlook 2001;49(6):254-257.

7. Lamb M, Storch JL. A historical perspective on nursing and nursing ethics. In: Storch JL, Rodney P, Starzomski R. Toward a moral horizon: nursing ethics for leadership and practice. 2nd ed. Toronto: Pearson Education; 2012. p. 20-40.

8. Storch JL, Rodney P, Starzomski R, editores. Toward a moral horizon: nursing ethics for leadership and practice. 2nd ed. Toronto: Pearson Education; 2012.

9. Carnevale FA. Considerações éticas em Enfermagem pediátrica. Rev Soc Bras Enferm Ped 2012;12(1):37-47.

10. Carnevale FA. La ética de la enfermería y la seguridad del paciente. In: Harada MJCS, Pedreira MLG. Enfermería a diario: la seguridad del paciente. Sao Paulo: Yendis; 2011. p. 61-68.

11. Pask EJ. Moral agency in nursing: seeing value in the work and believing that I make a difference. Nurs Ethics 2003;10(2):165-174.

12. Raines DA. Moral agency in nursing. Nurs Forum 1994;29(1):5-11.

13. Peter E. Fostering social justice: the possibilities of a 
socially connected model of moral agency. Can J Nur Res 2011;43(2):11-17.

14. Sherwin S. A relational approach to autonomy in health care. In: Sherwin S. The Politics of Women's Health: Exploring Agency and Autonomy. Philadelphia: Temple University Press; 1998. p. 19-47.

15. Corley MC, Elswick RK, Gorman M, Clor T. Development and evaluation of moral distress scale. J Adv Nurs 2001;33(2):250-256.

16. Barlem ELD, Lunardi VL, Lunardi GL, Dalmolin GL, Tomaschewski JG. Vivência do sofrimento moral na enfermagem: percepção da enfermeira. Rev Esc Enferm USP 2012; 46(3):681-688.

17. University of Alberta [internet homepage]. The experience and resolution of moral distress in paediatric intensive care teams: a Canadian perspective [access July 4 2013]. Available: http://www.picumoraldistress.ualberta. ca/en/Background/MoralDistressinthePICU.aspx

18. Carnevale FA, Benedetti M, Bonaldi A, Bravi E, Trabucco $G$, Biban $P$. Understanding the private worlds of physicians, nurses, and parents: a study of life-sustaining treatment decisions in Italian paediatric critical care. J Child Health Care 2011;15(4):334-349.

19. Meyer EC, Sellers DE, Browning DM, McGuffie K, Solomon MZ, Truog RD. Difficult conversations: improving communication skills and relational abilities in health care. Pediatr Crit Care Med 2009;10(3):352-359.

20. Barlem EL, Lunardi VL, Lunardi GL, Tomaschewski-Barlem JG, Silveira RS, Dalmolin GL. Moral distress in nursing personnel. Rev Latino-Am Enferm 2013;21(n. ${ }^{\circ}$ esp.):79-87.

21. Gaudine A, Lamb M, LeFort SM, Thorne L. Barriers and facilitators to consulting hospital clinical ethics committees. Nurs Ethics 2011;18(6):767-780.

22. Day L. Courage as a virtue necessary to good nursing practice. Am J Crit Care 2007;16(6):613-616.

23. Ethics Resource [internet homepage]. Moral Courage: definition and development. [access July 4 2013]. Available: http://www.ethics.org/files/u5/Moral Courage Definition and Development.pdf. 